DOI: 10.1515/pessr-2016-0021

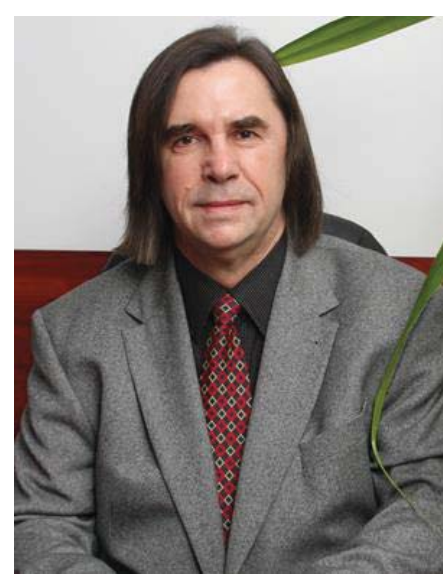

\title{
From Boxing to Philosophy
}

\author{
Jerzy Kosiewicz
}

KEYWORDS
Josef Pilsudski University of Physical Education in Warsaw, Poland 
cultural studies (specializing in theatre studies) at the same university's Faculty of Philology, and in 1986 he received a master's degree in theatre studies. He is also a graduate of Postgraduate Religious Studies at the Faculty of Social Sciences (1984).

His Ph.D. dissertation on the concept of man in the theory of physical culture (published after modifications under the title "Physical culture, personality, upbringing. Methodological issues," in Warsaw, 1986) was defended in 1984 at the Academy of Physical Education in Warsaw, granting Jerzy Kosiewicz a Ph.D. in physical education. The thesis was supervised by Professor Zbigniew Krawczyk. The habilitation colloquium was held in 1992 at the Cultural Institute of the Russian Academy of Sciences regarding the thesis entitled "The body and spirit as the object of Christian philosophical culture." The condition for admission to the colloquium was Jerzy Kosiewicz's book, entitled Man and His Body in the Orthodox and Catholic Doctrine (Moscow, 1992). As a result, the professor obtained the degree of "doktor habilitowany" (dr hab.; a Polish academic degree higher than a Ph.D.) in humanities in the field of philosophy. He underwent the habilitation procedure in Russia on the basis of his study of philosophical anthropology of the Russian Orthodox Church (mainly because of the need to use the so-called "prohibited materials," then only available with the special permission of the authorities in Moscow in the Library of the Russian Academy of Sciences INJON).

He obtained the degree of professor in 2003, and he was appointed as professor at the Józef Pilsudski Academy of Physical Education in 2004.

On 6 November 2009, he was awarded the title of Doctor Honoris Causa by the Senate of Semmelweis University in Budapest on the occasion of the $240^{\text {th }}$ anniversary of the medical university, which has been such an important place for European education.

He was also appointed as a member of the Commission of the Ministry of Science and Higher Education, evaluating proposals for the "Diamond Grant" in the years 2012-2014 and 2015-2017.

In 2014, Professor Jerzy Kosiewicz also became a member of the International Board of Advisors of the prestigious association of the American Sports Institute, located in Mill Valley, USA.

In 2016, he was elected to be a board member of the Warsaw Branch of the Polish Philosophical Society.

\section{Publications}

He is the author of over 800 publications (including more than 200 in English and nearly 10 in Russian). He wrote 9 books:

1. Kultura fizyczna, osobowość, wychowanie [Physical culture, personality and upbringing]. Zagadnienia metodologiczne [Methodological issues] (1986) Warsaw: Publishing House of Physical Education in Warsaw;

2. Czełowiek i jego tieło w doktrinie cerkwi i katoliczeskoj fiłosofii [Man and his body in the Orthodox and Catholic doctrine] (1992) Moskwa: Diełon. Iníon RAN (Russian Academy of Sciences), No. 46258;

3. Bóg, cielesność i przemoc [God, corporeality and violence] (1997) Warsaw: ALETHEIA;

4. Myśl wczesnochrześcijańska i katolicka wobec ciała [Early Christian and Catholic reflection on the body] (1998) Warsaw: Witmark;

5. Bóg, cielesność i miłość [God, body and love] (1998) Warsaw: ALETHEIA;

6. Kultura fizyczna i sport w perspektywie filozofii [Physical culture and sport in the perspective of philosophy] (2000), Warsaw: AWF Publishing House in Warsaw;

7. Filozoficzne aspekty kultury fizycznej i sportu [Philosophical aspects of physical culture and sport] (2004) Warsaw: Wydawnictwo BK Księgarnie;

8. Philosophy and Sport: From Methodology to Ethics (2010) Warszawa: Wydawnictwo BK Księgarnie;

9. Sports and Ethics: Philosophical Studies (2014) - a monograph published in the quarterly "Physical Culture and Sport. Studies and Research" No. 62, as a Special Issue. 
He is also the editor of two selections of philosophical texts:

1. Współczesna filozofia człowieka. Wybór tekstów [Contemporary philosophy of man - selection of texts] vol 1 and 2 (1985), selected and edited by J. Kosiewicz (scientific reviewer: R. Panasiuk), Warsaw: Wydawnictwo AWF w Warszawie;

2. Filozofia kultury fizycznej.Koncepcje i problem [Philosophy of physical culture. Concepts and problems.] vol 1 and 2 (1990), scientific editor: Z. Krawczyk, J. Kosiewicz, (scientific reviewer: J. Kuczynski), Warsaw: Wydawnictwo AWF w Warszawie.

$\mathrm{He}$ is also the editor and co-editor of 35 scientific collective works (including 20 in English):

1. Z zagadnień teorii i praktyki kultury fizycznej [Questions of theory and practice of physical education] (1985), scientific editors: J. Kosiewicz., A. Dąbrowski, Warsaw: Wydawnictwo AWF Warszawa;

2. Społeczne wartości kultury fizycznej [Social values of physical education] (1986), scientific editor Z. Krawczyk, J. Kosiewicz, R. Kaniuk, Warsaw: Wydawnictwo AWF Warszawa;

3. Marksizm po Marksie. Studia i szkice z dziejów filozofii marksistowskiej [Marxism after Marx. Studies from the history of Marxism.] (1989), scientific editor: W. Mackiewicz, A. Miś., J. Kosiewicz, K. Wojciechowski, M. Skwieciński, Warszawa: Wydawnictwo Uniwersytet Warszawski;

4. Sport $\mathrm{W}$ procesie integracji europejskiej [Sport in the process of European integration] (1998), scientific editors: J. Kosiewicz., Z. Krawczyk, K. Piłat, Warszawa: Wydawnictwo AWF Warszawa;

5. Sport in the Mirror of Values (2003) scientific editor: J. Kosiewicz and K. Obodyński, Rzeszów: Wydawnictwo Uniwersytet Rzeszowski;

6. Sports Involvement in Changing Europe (2004), scientific editors: J. Kosiewicz and K. Obodyński, Rzeszow: Wydawnictwo Uniwersytet Rzeszowski;

7. Sport and Society (2004), scientific editors: J. Kosiewicz, K. Obodyński, Rzeszów: Wydawnictwo Uniwersytet Rzeszowski;

8. Education through Sport: Towards an International Academy of Sport for All (2004), scientific editor H. Eichberg, J. Kosiewicz and others, Copenhagen: International Sport and Culture Association;

9. Axiological Dimensions of Sport - Practical Aspects (2004), scientific editors: J. Kosiewicz, K. Obodyński, Rzeszów: Wydawnictwo Uniwersytet Rzeszowski;

10. Physical Activity in Changing Europe (2004), scientific editor: J. Kosiewicz, L. Jaczynowski, Warszawa: Wydawnictwo AWF Warszawa;

11. Sport, Culture and Society (2005) scientific editor: J. Kosiewicz, Warszawa: Wydawnictwo AWF Warszawa;

12. Sport, kultura i społeczeństwo [Sport, culture and society] (2006) scientific editor: J. Kosiewicz, Warszawa: Wydawnictwo AWF Warszawa;

13. Social Differentiation of Tourism (2006) scientific editor: J. Kosiewicz, Warszawa: Wydawnictwo BK Księgarnie;

14. Movement Recreation for All (2006) scientific editor: J. Kosiewicz, Warszawa: Wydawnictwo BK Księgarnie;

15. Turystyka i rekreacja - wymiary teoretyczne i praktyczne [Tourism and other free time activity in theory and practice] (2006) scientific editors: J. Kosiewicz, K. Obodyński, Rzeszów: Wydawnictwo Uniwersytet Rzeszowski;

16. Sport and Values - Theoretical Foundations (2006) scientific editor: J. Kosiewicz, Warszawa: Wydawnictwo AWF Warszawa;

17. Sport for all as a form of education (2007) scientific editors: J. Kosiewicz., H. Eichberg, K. Obodyński, Rzeszów: Wydawnictwo Uniwersytet Rzeszowski;

18. Tourism in Borderlands - Multi-Aspect Study of Development (2007), scientific editor: K. Obodyński, J. Kosiewicz, W. Cynarski, Rzeszów: Wydawnictwo Uniwersytet Rzeszowski;

19. Społeczne i kulturowe wartości sportu [Social and cultural values of sport] (2007), scientific editor: J. Kosiewicz, Warszawa: Wydawnictwo AWF; 
20. Social and Cultural Aspects of Sport (2007) scientific editor: J. Kosiewicz., Warszawa; Wydawnictwo BK Księgarnie;

21. Social Sciences towards Contemporary Sport (2010) scientific editors: J. Kosiewicz, Piątkowska M., Żyśko J. Warszawa: Wydawnictwo BK Księgarnie;

22. Nauki społeczne wobec sportu współczesnego [Social sciences towords contemporary sport] (2010) scientific editors: J. Kosiewicz, M. Piątkowska, J. Żyśko, Warszawa: Wydawnictwo BK Księgarnie;

23. Sport in the Context of Social and Cultural Changes (2011) scientific editors: J. Kosiewicz, M. Piątkowska Warszawa: Wydawnictwo Muzeum Turystyki i Sportu;

24. Społeczne i kulturowe aspekty sportu [Social and culture aspects of sport] (2011) scientific editors: J. Kosiewicz, M. Piątkowska, Warszawa: Wydawnictwo Muzeum Turystyki i Sportu;

25. Sport in the Context of Social Sciences (2012) scientific editors: J. Kosiewicz., K. Obodyński K., W. Cynarski, Rzeszów: Wydawnictwo Uniwersytet Rzeszowski;

26. Kultura fizyczna i sport w zwierciadle nauk społecznych [Physical culture and sport in the mirror of social sciences] (2012) scientific editors: J. Kosiewicz., K. Obodyński, W. Cynarski; Rzeszów: Wydawnictwo Uniwersytet Rzeszowski;

27. Sport and Physical Culture in the Mirror of the Social Sciences (2013) Electronic book, Olomouc: Faculty of Physical Culture, Palacký University Olomouc, J. Kosiewicz, I. Jrasek, Donald N. Roberson, Jr. (Eds.) Olomouc;

28. Nauki społeczne wobec sportu i kultury fizycznej [Social sciences towards sport and physical culture] (2013) scientific editors: J. Kosiewicz. T. Michaluk K. Pezdek Wrocław: Wydawnictwo AWF Wrocław;

29. Sport i turystyka. Uwarunkowania historyczne i wyzwania współczesności [Sport and tourism. Historical and contemporary circumstances] (2013) scientific editors: M. Kazimierczak, J. Kosiewicz, Poznań: Wydawnictwo AWF Poznań;

30. Social Sciences of Sport. Assumptions and Perspectives (2013) scientific editors: J. Kosiewicz., K. Obodyński, Rzeszów: Wydawnictwo Uniwersytet Rzeszowski;

31. Kultura fizyczna i sport w zwierciadle nauk społecznych (2013) scientific editors: J. Kosiewicz, K. Obodyński, Rzeszów: Wydawnictwo Uniwersytet Rzeszowski;

32. Social Determinants of Sports Activity (2015) Eds.: D. Seabra, J. Kosiewicz, Porto: University of Fernando Pessoa;

33. Sport i turystyka w zwierciadle wartości społecznych (2015) scientific editors: M. Zowisło, J. Kosiewicz, Kraków: Wyd. Akademia Wychowania Fizycznego im. B. Czecha;

34. Z dziejów wychowania fizycznego, sportu i turystyki w Polsce i w Europie [The history of physical education, sport and tourism in Poland and Europe] (2016) scientific editors: J..Kosiewicz, E. Małolepszy., T. Drozdek-Małolepsza, Częstochowa: Wydawnictwo Akademii Jana Długosza;

35. Filozoficzne i społeczne aspekty sportu i turystyki [Philosophical and social aspects of sports and tourism] (2016) scientific editors: J. Kosiewicz, E. Małolepszy, T. Drozdek-Małolepsza, Częstochowa: Wydawnictwo Akademii Jana Długosza.

In addition, Professor Jerzy Kosiewicz as Editor-in-Chief has also published 26 editions (volumes) of the magazine Physical Culture and Sport. Studies and Research, which is now a quarterly. The amount of work related to each particular edition of the journal is much larger than editing and doing other work connected with issuing a collective work in a foreign language. The process of issuing the journal includes publishing both an electronic version and a printed one.

Publish and Perish, the widely available software created by Anne-Will Harzik and treated as a tool for researching the influence and citation of authors, shows (data retrieved on 30.05.2016) that Professor Jerzy Kosiewicz's work has 358 citations. Other Polish social scientists researching sport have achieved the following number of citations: Professor A. Pawłucki: 118; dr hab. M. Kazimierczak: 67; Professor Z. Dziubiński: 55; Professor J. Nowocień: 45; A. Smoleń, Ph.D.: 45; Professor A. Przyłuska: 34; dr hab. T. Michaluk: 26; Dr. M. Zawisło: 12; dr hab. H. Zdebska: 7. 
It should also be noted that, for example, issue 62 of the journal Physical Culture and Sport. Studies and Research, which includes a monograph by Jerzy Kosiewicz entitled Sport and Normative Ethics: Philosophical Studies, raised the interest of 791 (almost exclusively) English-speaking universities and research institutes from around the world in 2015. Academics, researchers and students entered the site and downloaded the content of the journal 1,770 times, based on data provided only by EBSCO, one of the 42 citation databases that are interested in Physical Culture and Sport. Studies and Research.

In the last three rankings of authors for 2013-2016 (as of 02.06.2016) regarding scientific publications at the Academy of Physical Education, Professor Jerzy Kosiewicz is ranked number one for the most published author based on the following:

- Total number of works. In the indicated period, Professor Kosiewicz wrote 56 texts. Other authors from the humanities and social sciences wrote fewer works: Jakub Adamczyk wrote 47, Prof. Dr. Z. Diubiński wrote 33 and Prof. Dr. Jerzy Nowocień wrote 29;

- The number of works granted points by the Ministry of Higher Education. In the period indicated, Jerzy Kosiewicz wrote 45 texts. Other authors from the humanities and social sciences wrote fewer works with this qualification: Dr. J. Adamczyk wrote 27, Prof. Dr. J. Nowocień wrote 24, Prof. Dr. Z. Dziubiński wrote 22 and Dr. A. Smoleń wrote 22;

- Value of points granted by the Ministry of Higher Education divided by the number of authors of the given publication. In the indicated period, Prof. Dr. Kosiewicz received 240,333 points. Other authors working in the humanities and social sciences received the following points: Prof. Dr. M. Guszkowska recevied 160,384 points; Prof. Dr. Z. Dziubiński received 117,222 points; and Prof. Dr. J. Nowocień received 99,000 points.

\section{Places of employment, positions and functions}

In the years 1973-1974, Professor Kosiewicz worked as a physical education teacher in the 101 Primary School, where he taught a judo sports class. His pupils won second place in the competition of primary schools in the field of judo in the school year of 1973-1974. He also worked in the IV Complex of Textile Vocational Schools and in several secondary schools in Łódź from 1974 to 1975. At that time, he was simultaneously employed as a judo coach in the Resursa Sports Club and TKKF Brzeziny. In addition, he worked as a wellness specialist in the period 1975-1976 at the Start Sports Club and as a boxing coach in the first league RTS Widzew in Łódź in the 1977-1978 season.

In the years 1975-1981, he was an assistant lecturer in the Department of Philosophy at the Medical University of Łódź, where he was admitted on the recommendation of Professor Wiesław Gromczyński as one of the most promising students of the second year of Philosophy at the University of Łódź. In 1981, for family reasons, he moved to Warsaw and began working in the Department of Philosophy and Sociology, then at the Department of Philosophy, and presently he is back in the Department of Philosophy and Sociology at the University of Physical Education in Warsaw.

From 1986 to 1990, he worked at the University of Warsaw. He was a co-founder of the Higher School of Economics and Technology in Legionowo and he was the Dean of the Faculty of Tourism and Recreation in 2001-2007. He was also employed as a professor at the School of Physical Culture and Tourism in Pruszków in 2001-2002, at the University of Rzeszów in the years 2003-2006, the State Higher Vocational School in Biała Podlaska in 2002-2005, and at the Higher School of Education and Administration in Poznan in the years 2006-2011. Between 1994 and 2007, he collaborated with the Institute of Physical Education, and later with the External Faculty of Physical Education in Biała Podlaska (AWF Warszawa).

At the Józef Piłsudski Academy of Physical Education (AWF) in Warsaw, which is his main place of work, Professor Jerzy Kosiewicz has held the positions of head of the Department of Philosophy (from 1993), head of the Department of Social Sciences (from 1999 to 2012) and head of the Department of Philosophy and Sociology (since 2012). He was chairman of the Academy Senate Committee, called the "Library Council," 
from 1996 to 2012. He also served two terms as vice president of the Senate Committee on Sports until 2012 and co-founded and served as head of Doctoral Studies in 1993-1999. He was a member of the Board of AZS (Academic Sport Association) at AWF in Warsaw in 1998-2006.

He served as chairman of the journal Studies and Monographs, as well as chairman of the Editorial Board of Scientific Annals of Physical Education in Warsaw. He established a journal on sport-related social sciences of an international character entitled Physical Culture and Sport. Studies and Research, ISSN: 20812221: eISSN 1899-4849, which is published in English and recently received 11 points in the ranking of Higher Education, and 89.43 in the Index Copernicus ranking (2014). The magazine is currently noted in 42 prestigious international citation databases.

In 2002, he was a co-founder of the journal European Journal for Sport and Society, ISSN: 1613-8171, published in Bern, Switzerland, under the auspices of the European Association for the Sociology of Sport. He was also a member of the editorial board of the journal in 2002-2009.

He is currently a member of editorial boards of 17 foreign scientific journals published in Europe, North America, South America, Asia and Africa, such as:

1. Editorial Board of the International Quarterly of Sport Sciences, ISSN: 2060- 9469, published in Budapest, Hungary.

2. Editorial Board of the International Journal of Eastern Sports \& Physical Education (IJESPE), ISSN: 1738-0866, published in Wauri, Bongdam, Hwa-Sung City, Gyunggi-Do, South Korea.

3. Editorial Board of the Journal of Aleşd (Asociacion Latinoamericana de Estudios Socioculturales del Deporte), issued in Curitiba, Brazil.

4. Advisory Board of the International Journal of Sport Motor Learning and Performance (IJMLSP), ISSN: 2230-8628, published in Bhagoo, Majra, Kharar, Punjab in India.

5. Editorship of the International Journal of Sports \& Health Education, published in Jalgaon, Pune, New Delhi, India.

6. Scientific Board of the journal Physical Culture. Journal of Sport Sciences and Physical Education, ISNN: 0350-3828, published at the University of Belgrade, Faculty of Sport and Physical Education, Serbia.

7. Redakčni rada (Editorial Board) of the journal Tèlesná Culture, ISSN: 1211 - 6521, published in Olomouc, Czech Republic.

8. Editorial Board of the Journal of Human Sport and Exercise, ISSN: 1988-5202, published by the University of Alicante, Spain.

9. Editorial Board Member of the Journal of Pro-Poor Growth. An International Perspective, ISSN: 2305-1669, published in Islamabad, Pakistan.

10. Editorial Board of the Journal of Sports Science, published in Libertyville, USA, ISSN: 2332-7839.

11. Editorial Board of the Journal of the Vasyl Stefanyk Precarapthian National University, ISSN: 23110155, published in Ivano-Frankivsk, Ukraine.

12. Editorial Board of the Scientific Journal of Physical Education and Sport, the International Edition, published by Helwan University in Cairo, Egypt.

13. Scientific Editorial Board of the International Journal of Physical Education \& Sports Sciences Elite, published in Guawahati, Assam, India.

14. Editorial Board of the Journal of Sports Science and Physical Education Applications, published at South Valley University, Qena, Egypt.

15. Editorial Board of Geosport for Society Scientific Journal of Geography, Physical Education and Sport, edited by Oradea University Press, Romania.

16. Editorial Board of the Journal of Applied Sports Science, published at Alexandria University, Egypt, ISSN: 2357-0059 (online), ISSN: 2357-0024.

17. International Scientific Committee (Comitate Scientifico Internationale) of the Italian Journal of Sports Pedagogy, edited by Universita di Roma "Foro Italico" and Unversiteta di Napoli "Parthenope," Napoli, Italia, ISSN: 2499-541X. 
Professor Jerzy Kosiewicz also cooperates with the Roman academic publishing house as a member of: Scientific Committee of the "Education and Sport Studies" series of books published by Edizioni Nuova Cultura (scientific publisher of Rome), Rome, Italy.

In addition, Professor Jerzy Kosiewicz is a member of the following Polish editorial boards:

1. Editorial Board of Studies for Sports Humanities, formerly Studies in the Humanities, ISSN: 1641-8573, published at the Academy for Physical Education in Cracow.

2. Scientific Board of the Scientific Review of Physical Culture of the University of Rzeszów, ISSN: 17327156, currently Scientific Review of Physical Culture, ISSN: 2083-859X.

3. Scientific Board of "Ido. Movement for Culture." Journal of Martial Arts Anthropology, ISSN: PL1730-2064, published in Rzeszów.

4. Scientific Board of Physical Culture, ISSN: 1505-4241, published by Jan Długosz Academy in Częstochowa.

5. Scientific Board of Research Papers, ISSN: 0239-4375, published by the Academy of Physical Education in Wroclaw.

He was:

1. Vice chairman of the Editorial Board of Teaching Publications of the Academy of Physical Education in Warsaw.

2. A member of the Editorial Board of the Research Yearbook. Studies in the Theory of Physical Education and Sport.

3. A member for many years of the Editorial Board of Philosophical Education magazine, founded and published under the auspices of the University of Warsaw.

In addition, Professor Jerzy Kosiewicz was a participant and gave presentations at a large number of scientific conferences at the following universities: Sunderland (United Kingdom), Cardiff (3 times, United Kingdom), Leeds (United Kingdom), York (United Kingdom), Dundee (United Kingdom), Cheltenham (United Kingdom), Gloucester (UK), Eastbourne (United Kingdom), Liverpool (UK), Seattle (USA), Rochester (USA), Fullerton (USA), Montreal (Canada), Niagara Falls (Canada), Kyoto (Japan), Tokyo (Japan), Seoul (Korea), Brisbane (Australia), Budapest (8 times, Hungary), Olomouc (6 times, Czech Republic), Bratislava (2 times, Slovakia), Prague (Czech Republic), St. Petersburg (Russia), Nizhny Novgorod (Russia), Simferopol (Ukraine), Utrecht (2 times, Netherlands), Neimehen (Netherlands), Amsterdam (Netherlands), Rome (3 times, Italy), Porto (3 times, Portugal), Estoril (Portugal), Lyon (France), Paris (France), Cordoba (Spain), Freizing (Germany), Munich (Germany), Munster (Germany), Cologne (3 times, Germany), Bielefeld (Germany), Oslo (2 times, Norway), Jyvaskyla (Finland), Stockholm (2 times, Sweden), Copenhagen (Denmark), Aarhus (Denmark), Bern (Switzerland), Lausanne (Switzerland), Bled (Slovenia), Ljubljana (Slovenia), Vienna (2 times, Austria), Athens (5 times, Greece), Kalamata (Greece), Pithagorio (2 times, Samos, Greece), Pafos (Cyprus), Heraklion (Crete, Greece).

In addition, Professor Jerzy Kosiewicz visited the following places, among others, in connection with his own and international research, as well the proceedings of the boards of scientific societies in which he took part: Portland (USA), Copenhagen (4 times, Denmark), Rome (Italy), Jyvaskyla (Finland), Oslo (Norway), Budapest (2 times, Hungary), Cologne (Germany), Zurich (Switzerland), Vienna (3 times, Austria), Stirling (United Kingdom), Leipzig (Germany), Moscow (2 times, Russia).

For many of these visits, he was invited as a keynote speaker.

His notes cover only the years since 2004 and include: 
a) 2004.

- Conference of the British Philosophy of Sport Association, Durham, England,

- Scientific conference of the European Movement of Fair Play, Vienna, Austria,

b) 2007

- Scientific conference of the Association of Latinnoamericana de Sociologia in Gualdajara, Mexico,

- Scientific conference of Universidad Iberoamericano in Mexico City, Mexico,

- Scientific conference of Unversidad de Colima, Mexico,

c) 2008

- First Congress of ALESDE, Curitiba, Brazil,

d) 2009

- Scientific conference of the International Association for Far Eastern Sports and Physical Education, Chengdu, China,

- Scientific conference of the International Association for Far Eastern Sports and Physical Education, Taipei, Taiwan,

- Scientific conference in Warsaw,

e) 2010

- Scientific conference of the European Association of the Sport Science Antalaya, Turkey,

- Scientific conference in Warsaw,

f) 2011

- Scientific conference in Olomouc, Czech Republic,

g) 2012

- Conference in Koper, Slovenia,

- Scientific conference of the International Association for Far Eastern Sports and Physical Education in Manila, Philippines,

- International conference at Helvan University in Cairo, Egypt,

- Twelth International Sport Science Congress in Denizli, Turkey,

h) 2013

- Scientific conference at the University of Amravati: $100^{\text {th }}$ Anniversary, SHREE, H.F.P., Mandal Amravati, India

- A scientific conference in Porto, Portugal,

- Conference on research at Jan Amos Komensky University, Bratislava, Slovakia,

i) 2014

- Global Scientific Conference on Physical Education, Health \& Sports Sciences, University of Amristar, Punjab, India,

- Conference of the International Association for Far Eastern Sports and Physical Education, Visva Bharati University, India,

- International Scientific Conference, Basrah, Iraq,

- Scientific conference of Osmania University, Hyderabad, India,

- Scientific conference in Kaunas, Lithuania,

j) 2015

- Scientific Conference at the University of Physical Education in Budapest, Hungary,

- Scientific Conference at the University of Aswan, Egypt,

- Scientific Conference at Jan Amos Komensky University in Bratislava, Slovakia, 


\section{k) 2016}

- Scientific Conference at the University of Isfahan, Iran,

- Scientific Conference at Anadolu University, Turkey.

Professor Jerzy Kosiewicz was also frequently invited to give lectures as a visiting professor at the following universities:

- Palacky University in Olomouc in Czech Republic (5 times),

- Semmelweis University in Budapest, Hungary (5 times),

- University of Jyväskylä, Finland (3 times),

- Norwegian School of Sport Sciences in Oslo, Norway (3 times),

- Deutschen Sporthochschule Koeln, Germany (2 times),

- Univerziteta Jana Amosa Komenskeho in Bratislava, Slovakia (2 times),

- Universidad de Las Palmas Gran Canaria (2 times), Spain,

- Lithuanian Academy of Physical Education in Kaunas, Lithuania,

- Universidad de Colima in Mexico,

- La Universidad de Gualdajara in Mexico,

- Universidad Iberoamericano in Mexico City, Mexico,

- University of Southern Denmark in Odense, Denmark,

- University of Stirling, UK;

- Università degli Studi di Roma "Foro Italico" in Italy,

- School of Education at the Polytechnic Institute of Viseu in Portugal,

- University of Florence, Italy,

- Universität Leipzig, Germany,

- Dalarna University in Sweden.

Professor Jerzy Kosiewicz took the honorary patronage as chairman of the International Society for the Social Sciences of Sport of the International Conference on "The Interaction of Sport and Society in the V4 Countries." It was held at the Hungarian Academy of Sciences in November 2011 and concerned the four Visegrad countries. It was opened by Hungary's Deputy Minister of Foreign Affairs.

Jerzy Kosiewicz has also hosted visiting professors who gave lectures in the philosophy and sociology of sport, such as:

- Gyongyi Foldesi of Semmelweis University (Budapest, Hungary) - 6 times,

- Bohuslav Hodan of Palacky University (Olomouc, Czech Republic) - 5 times,

- Ivo Jirásek of Palacky University (Olomouc, Czech Republic) - 5 times,

- Ejgil Jespersen of the Norwegian School of Sport Sciences (Oslo, Norway) - 4 times,

- Otmar Weiss of the Institut für Sportwisenschaft der Universität (Vienna, Austria) - 3 times,

- Georg Anders of the Bundesinstitut für Sportwissenschaft (Bonn, Germany) - 2 times,

- Kimmo Suomi of the University of Jyväskylä (Finland) - 2 times,

- Emanuele Isidori of Universita degli di Roma "Foro Italico" (Italy) - 2 times,

- Arno Müller of Leipzig University (Germany) - 2 times,

- Patrizia Zagnoli of the University of Florence (Italy) - 2 times,

- Elena Radicchi of the University of Florence (Italy) - 2 times,

- Grant Jarvie of the University of Stirling (Stirling, Scotland),

- Sigmund Løland, Rector of the Norwegian School of Sport Sciences (Oslo, Norway),

- Bart Crum of the Free University (Amsterdam, Netherlands),

- Erdem Cigerci of Kastamonu University (Turkey),

- Mait Arvisto of Tallinn Pedagogical University (Estonia), 
- Dušan Leška of Univerzita Komenského (Bratislava, Slovakia),

- Saulius Kavaliauskas of the Lithuanian Academy of Physical Education (Kaunas, Lithuania),

- Roger Melin of Dalarna University in Falun (Sweden),

- Henning Eichberg of the University of Southern Denmark (Odense, Denmark).

Professor Jerzy Kosiewicz is a member of the following scientific societies:

1. International Society for the Social Sciences of Sport (ISSSS - founder: 2009; president of the society from the beginning of its existence),

2. European Association for the Sociology of Sport (EASS - founder, together with Professor Dr. Otmar Weise, in 2001; he served as vice president from 2001 to 2008),

3. European Association for the Philosophy of Sport (EAPS - a member of the Founding Committee, 2008; member of the board for two terms from 2008 to 2014),

4. International Association for the Philosophy of Sport (IAPS - member since 2002),

5. British Philosophy of Sport Association (BPSA - member since 2002),

6. International Sociology of Sport Association (ISSA - member since 1991),

7. International Society for Universal Dialogue (ISUD - member since 1989; member of the Founding Committee; chairman of the Organizing Committee of the Founding Congress in 1989),

8. European Society for the Study of Science and Theology (ESSSAT - member since 1994),

9. Polish Philosophical Society (PTF - member since 1976; member of the board of PTF - Warsaw Branch since 2016),

10. Polish Society of Religious Studies (PTR - member since 1982),

11. Polish Societies of Social Sciences on Sport (PTNSS - founder in 2009, and has since served as president),

12. Polish Society for Sciences of Physical Education (PTNKF - member since 1982),

13. International Material Arts and Combat Sports Scientific Society (IMACSSS - member since 2011).

He has also been a long-standing member of the following scientific societies: European Association for the Management of Sport, International Sport and Culture Association, International Academy of Sport for All and the International Academy for Sports Leaders.

Professor Jerzy Kosiewicz is also involved in theatre. He has been a member of the Association of Polish Artists since 1997 and the International Federation of Actors (FIA) since 1997. He served for many terms and remains involved as deputy chairman of the Section of Theatre Critics. He has also served as chairman of the Distinctions Committee of ZASP (Polish Actors' Association), member of the Committee for the Creation of the Institute of Theatre Arts and member of the Program Council of the Association. He is now a member of the Committee for Monitoring the Situation of Public Theatres in Poland and the Working Group for Creating the Book of Good Practices.

Although he is currently less active than he used to be, Professor Jerzy Kosiewicz is also a theatre critic and reviewer. He has published more than 40 articles related to theatre, and several on film theory.

\section{Teaching achievements and supervised theses}

Professor Jerzy Kosiewicz gives lectures and teaches classes at the Faculty of Physical Education in the history of philosophy, philosophy of man, and philosophy of nature and ethics. He also conducts MA and BA seminars and classes in philosophy and ethics, as well as separate classes on ethics in English for foreign students within the framework of the Erasmus Programme.

He has also been the supervisor of over 300 MA and BA theses at AWF in Warsaw (and the branch in Biała Podlaska), Rzeszów University, the Economic and Technical University in Legionowo, the State High Vocational School in Biała Podlaska and the High School of Pedagogy and Administration in Poznań. 
For several years, Professor Jerzy Kosiewicz has conducted classes for post-graduate students in the field of general methodology as a philosophical discipline (in particular, regarding empirical sciences and the humanities), the history of philosophy and formal logic.

He has also been invited to several foreign international conferences of students as a juror and a member of scientific committees.

Professor Jerzy Kosiewicz has supervised 8 Ph.D. theses:

1. Jakub Mosz, Ph.D. - "The image of professional sports in the Polish documentary film”, 1997,

2. Wojciech Cynarski, Ph.D. - "Far Eastern martial arts in Western culture", 1998,

3. Konrad Zieliński, Ph.D. - "The concept of man in the Polish theory of physical education", 2000,

4. Jaroslaw Kudelski, Ph.D. - "Sources and transformations of ideology and philosophy of Olympism," 2003 ,

5. Joanna Femiak, Ph.D. - "The concept of the body in the sciences of physical culture", 2005,

6. Tomasz Wasążnik, Ph.D. - "The system of values in physical culture and postmodern crisis of culture", 2015 ,

7. Rafał Biały, Ph.D. - "Personalism and competitive sport", 2015,

8. Zoltan Marczcinka, Ph.D. from Hungary - "The decisive factors that influence success in handball: Based on the analysis of a World Championship", 2015.

Professor Kosiewicz is now supervising the theses of two other graduate students.

One of the above Ph.D. students, dr hab. Professor Wojciech Cynarski, was awarded the title of professor by the Central Commission for Academic Degrees and Titles at the end of 2015.

Professor Jerzy Kosiewicz has also supervised two academics of the Department of Philosophy, which he is heading, in achieving the degree of doktor habilitowany (a Polish academic degree higher than Ph.D.):

- Alicja Przyłuska-Fiszer, Ph.D., in 1997 - Rector of the Academy of Physical Education in Warsaw in the years 2008-2012,

- Henryk Benisz, Ph.D., in 2001.

Przyłuska-Fiszer received her degree on the basis of the thesis "Ethical aspects of the dispute on abortion" (Warsaw, Physical Education Publishing House, 1997) at the Institute of Philosophy of the University of Warsaw in 1998. She was awarded the title of professor in 2015. Henryk Benisz, Ph.D., received his degree on the basis of the thesis "Nietzsche and Dionysian Philosophy" (Warsaw, Physical Education Publishing House, 2001) at the Institute of Philosophy and Sociology of the Polish Academy of Sciences in 2002.

In the Department of Social Sciences and the Department of Philosophy and Sociology headed by Professor Jerzy Kosiewicz, the following academics obtained the degree of doktor habilitowany: Jolanta Zyśko, Ph.D.; Krzysztof Jankowski, Ph.D.; Michał Lenartowicz, Ph.D.; and Zbigniew Dziubiński was promoted to be a professor in 2014.

Professor Jerzy Kosiewicz participated in 4 foreign habilitation procedures:

1. The first was related to the dissertation of Ivo Jirasek, Ph.D., from Palacky University in Olomouc (2006),

2. The second was initiated and finalized in 2007 at the University of Prešov and concerned Stanislaw Cieszkowski, Ph.D.,

3. The third concerned Zbigniew Barabasz, Ph.D., and was initiated at the University of Prešov in 2011,

4. The fourth concerned Emilian Zadarko, MD, Ph.D., at Univerzita Mateja Bela in Banská Bystrica in 2013. 
Professor Jerzy Kosiewicz also participated 5 times in foreign procedures related to obtaining the academic title and degree of professor:

1. Professor Anna Hogenova from Charles University in Prague; the procedure was initiated at Palacky University in Olomouc,

2. The above-mentioned Professor Ivo Jirasek of Palacky University in Olomouc,

3. Professor Aleš Sekot of Masaryk University in Brno,

4. Professor Ludmila Fialova of Charles University in Prague,

5. Professor Jarmo Liukkonen from the University of Jyvaskyla in Finland.

Professor Kosiewicz has also reviewed four doctoral theses at Semmelweis University in Budapest.

Three Ph.D. theses were prepared under the supervision of Professor Dr. Gyöngyi Földesi:

1. The thesis of Lappas Kleomensis, "On the Deviant Behavior of Greek Football Spectators" (2005),

2. The dissertation of Antonis Alexopulos, "Sport in the European Union from a Cypriot Perspective" (2007),

3. The Ph.D. work of Diana Christodoulou, "Social Status of Qualified Physical Education Teachers in Cyprus" (2011),

4. The fourth thesis by Hamidrez Mirsafian, Ph.D., entitled "Constraints in Physical Activity and Sport: A Comparative Study Between Hungarian and Iranian Students" (2014), was written under the joint supervision of Professor Gyongy Földesi and Gabor Geczi, Ph.D.

Professor Jerzy Kosiewicz has also reviewed 3 doctoral dissertations in the field of social philosophy at the Catholic University of Lublin:

- The doctoral dissertation of Piotr Szulich, “Adam Rodziński’s concept of social personalism” (2002),

- Tomasz Czernik's thesis, "The concept of man and community in the views of George Santayana" (2003),

- The Ph.D. thesis of Stanisław Srebro, entitled “Józef Tischner's concept of social life” (2006).

The supervisor of these theses was Professor Stanisław Kowalczyk.

Professor Jerzy Kosiewicz has reviewed several dozen doctoral theses, dissertations and other works connected with granting the degree of professor.

\section{Academic interests}

Generally speaking, the academic interests of Professor Jerzy Kosiewicz primarily concern research in the field of philosophical anthropology (on the sources and transformations of the Christian concept of the body), the philosophy of religion, ancient Greek philosophy, general methodology and the philosophy of physical culture and sports. He has also dealt with issues related to the cultural and educational aspects of tourism and recreation.

In his works, Professor Jerzy Kosiewicz has often taken a controversial new approach to commonly accepted issues and assumptions. This includes denying the existence of the philosophy of sport as an independent and mature field of study and rejecting the whole concept of free time in the philosophical (e.g. in the Aristotelian) and non-philosophical sense for the sake of the concept of busy time both in the case of human life and the life of other organic beings. He also believes that one should not consider sport activity from the point of view of good and evil, i.e. of morality. In the context of the achievements of Pythagorean astronomy and the philosophy of space, he also disputes the uniqueness of the so-called Copernican revolution. Many find it controversial that he indicates that one of the main sources of anthropology, culture and European theatre is, in terms of its inspiration, a multifaceted concept of Eros (representing the philosophical base of the Platonic philosophy of culture) and the practical sense of the activity of Bacchantes, in particular their 
carnivalised religious forms. He follows Karl Popper, Thomas Kuhn and Imre Lakatos in negating the concept of the use of hypotheses in empirical sciences.

Professor Jerzy Kosiewicz also focuses his attention on axiological problems related to the exploration and study of the source, meaning and ways of the manifestation and impact of values in general as well as in physical culture and sport. He has also dealt with issues from the field of philosophical anthropology, the analysis of the human being in the light of the dynamic theory of man and interpretation of the subject as a being composed of three ontic layers: relational (social), ideal (mental) and material (physical). This created the basis for formulating - on the grounds of the philosophy of physical culture - the concept of the personality and health of ontological and phenomenal status, understood as entities that may or may not appear, and if they exist, they exist as ontic fact, mediated in man and in society, which means that they can be considered from the ontological point of view.

Thus, personality and health for Professor Jerzy Kosiewicz form the foundation for a recognized philosophical pedagogy of physical culture - the field whose aim is to educate, develop and improve man according to the goals and ideals of education connected with axiology, the source and meaning of physical culture. Reflection on the pedagogy of physical culture has been interpreted in the light of the general principles of Hessen's philosophy of culture and education as a part of the philosophy of physical culture, that is, as a philosophy of implementing the established world of values, and on this basis changing the ontic layers of the individual and the individual's personality and health, developing and shaping the human being as the subject of culture and civilization.

The academic interests of Professor Jerzy Kosiewicz also include methodological issues, i.e. the analysis of the logical structure of optimization propositions in pedagogy and pedagogical assumptions of physical culture on the basis of the theory of physical education and other sub-disciplines within the scope of this pedagogy (health education, education through sport, education in praxeological terms, theory of training and theory of combat sports). He arrived at the conclusion that the pedagogy of physical culture (and its subdiscipline) is a classical practical field, within which one specifies aims, sets of values, ideals of education and the personality and health of a teleological and optimization character, while also determining how they should be implemented, including the areas and options of practical activities. These concepts have been considered by Professor Kosiewicz and enriched with extensive deliberations in the field of general methodology and the philosophy of science and science studies, which he presented, among others, in the works "The methodology and hypothesis", "Methodology as a form of agnosticism" and "Verification and hypothesis".

He also focuses his academic attention on the issues of the body in Christian anthropology from a historical perspective, from Orphism to the present times. These are the subjects of his three frequently reprinted books: God, Corporeality and Violence (1997), Early Christian and Catholic Reflection on the Body (1998), God, Corporeality and Love (1998) and the monograph published in Moscow under the title Man and His Body in the Orthodox and Catholic Doctrine (1992, Russian Academy of Sciences). The above works cover more than three thousand years of religious, theological and philosophical reflection of the European culture, where the author emphasizes the Judaic and Hellenic roots of Christian anthropology and how the early Christian foundation formed for the development of the Catholic concept of man and varied relations to the human body. These works also present an analysis of the contemporary form of Catholic anthropology, which is under the significant impact of biblical and Greek and Roman ideas of man. They also discuss the attitude of Russian Orthodoxy and Protestantism to the human body and its needs. Reflections on ancient roots and various forms of Christian anthropology, and especially the concepts of the human body, are particularly helpful in explaining the negative attitude of the Christian Church to physicality and physical activity that has lasted for almost two millennia. This applies to the Patristic period: the early Christian, medieval, modern and present times. This explanation may be useful for understanding the reasons for revaluating this stance of Catholicism, Orthodoxy and Protestantism in the twentieth century, as well as the far-reaching affirmation of the body and its needs in various forms of physical activity. 
Kosiewicz's studies in the philosophy of religion and Christian anthropology have been commented on in the PWN Encyclopaedia of Religion and may be found under the entry "Kosiewicz" (Warszawa, vol. 6, 2003, p. 55).

Another sphere of the professor's philosophical inquiry is associated with ancient Greek philosophy and its influence on the thought and culture of the West. He emphasizes the birth and transformation of this philosophy, as well as its etymological, ontological, epistemological and anthropological grounds and conditions. In relation to these issues, he dwells on the religious and cognitive conditions of Pythagoreanism, refers to the relations between the agnosticism of Socrates and the modern epistemological scepticism and considers issues related to physicality, sexuality and erotic love in the context of the Platonic philosophy of culture saturated with divine elements: the frenzy of creativity, including the variously manifested desire for immortality. He inspects ancient perceptions of time in general, as well as their impact on the theories of being and time formulated by Descartes, Kant and Heidegger. This also applies to relations between the Pythagorean and post-Pythagorean philosophy of the universe and Copernican astronomy and its Kantian and Nietzschean reception. A manifestation of this activity is not only membership and participation in the seminars and annual conferences of the International Association of Greek Philosophy, but also many English-language publications recommended by this institution (the volume of these materials is 12,314 publisher's sheets). These include, among others:

- Kosiewicz, J. (2009). Plato's Eros and the issue of erotic love in the views of John Paul II. In K. Bourdouris \& M. Adam (Eds.), Greek Philosophy and the Issue of Our Age, vol. II, p. 146-167. Athens: Ionia Publications, 1.55 publisher's sheets,

- Kosiewicz, J. (2009). Socrates' attitude towards knowledge and morality. Anthropological and agnostic consequences. In K. Boudouris \& M. Adam (Eds.), Greek Philosophy and the Issue of Our Age, vol. I, p. 104-123. Athens: Ionia Publications, 1.52 publisher's sheets,

- Kosiewicz, J. (2011). Ancient Greek and Copernican philosophy of the cosmos from the point of view of Kant and Nietzsche. In K. Boudouris (Ed.), Philosophy, Art and Technology, p. 158-167. Athens: Ionia Publications, 0.77 publisher's sheets,

- Kosiewicz, J. (2014). Free and occupied time in the context of ancient Greek and contemporary philosophy. In M. Adam \& K. Boudouris (Eds.), Philosophy, Politics and Economics, p. 128-152, first electronic edition. Athens: Ionia Publications, 1.72 publisher's sheets. ISBN: 978-960-7670-76-2,

- Kosiewicz, J. (2014). The body, sex and erotic love in the context of Plato's philosophy of culture. In S. Boudouris \& K. Kalimtzis (Eds.), Issues in Human Relations and Environmental Philosophy, p. 145175, first electronic edition. Athens: Ionia Publications, 2.34 publisher's sheets. ISBN: 978-960-7670$75-5$,

- Kosiewicz, J. (2014). Philosophy in the crucible of etymology, madness and cognition. In S. Boudouris \& K. Kalimtzis (Eds.), Issues in Human Relations and Environmental Philosophy, p. 177-2112, first electronic edition. Athens: Ionia Publications, 784 publisher's sheets. ISBN: 978-960-7670-75-5,

- Kosiewicz, J. (2015). Religious and philosophical determinants of Pythagoreanism. In M. Adam \& M. Veneti (Eds.), Greek Philosophy and Political and Moral Issue, p. 160-187, electronic edition. Athens: Ionia Publications, 1.65 publisher's sheets. ISBN: 978-960-7670-80-9.

This also applies to two books on the above issues which will be published in print by the end of this and the beginning of next year in English and Polish.

Since 2003, Professor Jerzy Kosiewicz has headed three international collaborative research groups in the field of the social sciences of sport that included representatives of 8 countries: Austria, Germany, Belgium, Czech Republic, Hungary, Estonia, Russia and Poland. The research subsequently included participants from 13 countries, including Finland, Denmark, Norway, Slovakia and Greece. These studies concerned:

1.Values and cultural patterns in sport (complementary-comparative study) - from 2003 to 2006,

2. Social and cultural values of sport - from 2006 to 2009 ,

3. Sport in the process of social and cultural transformations in Central Europe - from 2010 to 2013. 
The above studies were conducted under the auspices of the Ministry of Science and Higher Education (and its earlier counterparts), Józef Pilsudski University of Physical Education in Warsaw and the European Association for the Sociology of Sport, as well as the International Society for the Social Sciences of Sport and the Polish Society of Social Sciences of Sports. All of the above-mentioned books that were published after 2003 (in English and Polish) have been associated with the above research and concerned mainly the philosophy and sociology of sport, the organization of physical culture and sports psychology and pedagogy.

In 2004, Professor Kosiewicz participated in two autonomous studies in the framework of grants from the European Commission carried out by:

1. The European Academy for Sports Leaders (under the auspices of the International Society for Sports and Culture) and

2. The European Academy of Sport for All (also under the patronage of ISCA).

\section{Academic awards}

Professor Jerzy Kosiewicz has received five ministerial awards for academic achievements:

He has received Individual Awards of the $1^{\text {st }}$ Degree three times:

1. Minister of Physical Culture and Tourism in 1993,

2. Minister of Sport in 2005

3. Minister of Science and Higher Education in 2007

as well as the following:

1. Award of the $2^{\text {nd }}$ Degree of the Minister of Science and Higher Education in 2011, and

2. Award of the $3^{\text {rd }}$ Degree of the Minister of Health and Social Welfare in 1980.

He also received the $1^{\text {st }}$ Degree Award of the Rector of the Academy of Physical Education in Warsaw and many Rector's $2^{\text {nd }}$ and $3^{\text {rd }}$ Degree awards.

$\begin{array}{ll}\text { AUTHOR'S ADDRESS: } & \text { Jerzy Kosiewicz } \\ & \text { Department of Philosophy and Sociology } \\ & \text { Josef Pilsudski University of Physical Education in Warsaw } \\ & \text { Marymoncka } 34 \\ & \text { 00-968 Warsaw, Poland } \\ & \text { E-mail: jerzy.kosiewicz@awf.edu.pl }\end{array}$

Received: 1 August 2016; Accepted: 21 September 2016 